\title{
Perbaikan dan pemeliharaan mesin disc mill bongkol jagung
}

\author{
Adhan Efendi' ${ }^{1)}$, Roni Suhartono ${ }^{2)}$ \\ 1), 2) Jurusan Pemeliharaan Mesin, Politeknik Negeri Subang \\ E-mail:1)adhan@polsub.ac.id, ${ }^{2}$ roni.suhartono@polsub.ac.id
}

\begin{abstract}
Abstrak
Pembuatan pakan ternak ruminansia terdiri dari dedak, ampas kecap, mineral, urea, garam dan limbah bongkol jagung. Limbah bongkol jagung diolah menjadi partikel yang lebih kecil menggunakan mesin disc mill. Mesin disc mill milik kelompok ternak Budi Asih mengalami kerusakan pada bearing dan sabuk v-belt. Penelitian ini bertujuan untuk membantu dalam proses perbaikan dan pemeliharaan mesin disc mill tersebut. Metode pengambilan data dilakukan melalui dokumentasi kemudian data diolah secara deskriptif kualitatif. Hasil penelitian menunjukkan bahwa: (1) Alat dan bahan yang digunakan dalam proses perbaikan mesin disc mill adalah tool box lengkap (kunci ring dan pas), WD-40, tang, palu, obeng plus dan min, gerinda, mata gerinda, tracker, jangka sorong, mistar, minyak gemuk, oli, kain majun, dan amplas halus; (2) Langkah-langkah perbaikan bearing dan sabuk v-belt pada mesin disc mill adalah membuka pengunci mesin bagian depan, memisahkan pisau pemotong dan saringan dari rumah mesin disc mill, melepaskan sabuk v-belt dan mur pengunci, melepaskan poros engkol dengan menggunakan palu, gunakan traker untuk melepaskan puli dan bearing, ukur diameter bearing menggunakan jangka sorong, amati kerusakan pada poros engkol dan bearing, berikan oli pelumas pada poros engkol, ganti bearing se-tipe yang baru, pasang kembali bearing ke poros engkol, berikan minyak gemuk pada bearing, pasang kembali poros engkol ke mesin disc mill, pasang kembali pisau pemotong dan saringan, kendorkan mur dan pasang kembali sabuk v-belt yang baru, langkah terakhir bersihkan mesin dengan kain majun; dan (3) Perencanaan perawatan mesin melalui validasi ahli, perawatan yang dipilih yaitu perawatan bulanan dengan metode ISMO.
\end{abstract}

Kata Kunci: Disc Mill, Perbaikan, dan Perawatan..

Abstract

The manufacture of ruminant animal feed consists of bran, soy sauce pulp, minerals, urea, salt and corncob waste. Corncob waste is processed into smaller particles using a disc mill machine. The Budi Asih cattle group's disc mill has suffered damage to the bearing and v-belt. This study aims to assist in the process of repairing and maintaining the disc mill machine. Data collection method is done through documentation which is processed in a descriptive qualitative. The results showed that: (1) Tools and materials used in the process of repairing disc mill machines were complete tool boxes (lock ring and fitting), WD-40, pliers, hammers, plus and min screwdrivers, grinders, grinding eyes, tracker, shovel term, ruler, grease oil, oil, cloth, and fine sandpaper; (2) The step of bearing repair and $v$-belt belts on disc mill machines are: opening the disc mill machine lock, separating cutting blades and disc mill machine filters, removing the v-belt belt and locking nut, releasing the crankshaft using a hammer, using a traker to release pulleys and bearings, measuring the diameter of the bearing using calipers, observing the damage that occured on the crankshaft and bearing, giving lubricating oil to the crankshaft, replacing the bearing of a new type, re- 
attaching the bearing to the crankshaft, giving grease to the bearing, reinstalling the crankshaft to disc mill machineand the cutting blade and filter, loosening the nut and replacing the new v-belt, the last steping cleaning the machine with a rag; and (3) Planning machine maintenance through expert validation, the chosen treatment is monthly maintenance with the ISMO method.

Keywords: Disc Mill, Maintenance, and Repair.

\section{PENDAHULUAN}

Perkembangan teknologi tepat guna di bidang perternakan mengalami banyak inovasi terutama dalam proses pembuatan mesin penunjang hasil perternakan. Mesin dibuat dengan berbagai tujuan tergantung spesifikasi dan kegunaan mesin tersebut. Salah satu mesin dalam bidang pembuatan pakan ternak adalah mesin disc mill. Mesin disc mill digunakan dalam proses penghancuran bongkol jagung menjadi tepung, tepung dari hasil bongkol jagung ini akan digabungkan dengan komponen lain sehingga membentuk sebuah pakan ruminansia untuk pakan sapi ternak.

Jagung merupakan komoditas yang memiliki peran penting di bidang pangan dan pakan [1]. Selama ini jagung hanya dimanfaatkan bijinya saja dan dimanfaatkan untuk pemipil jagung [2]. Setelah proses tersebut bongkol jagung yang dibuang dan menjadi limbah jagung. Namun dengan kemajuan bidang penelitian saat ini bongkol jagung dijadikan sebagai campuran pembuatan pakan ruminansia, hal tersebut dikarenakan bongkol jagung merupakan limbah yang kaya akan nutrisi

Bongkol jagung merupakan limbah pertanian yang memiliki nutrisi tinggi untuk memenuhi kebutuhan sapi ternak. Kandungan nutrisi limbah bongkol jagung bahan kering meliputi kadar air $(29,54 \%)$, bahan kering $(70,45 \%)$, protein kasar $(2,67 \%)$ dan serat kasar $(46,54)$ [3]. Penghancuran bongkol jagung menjadi partikel-partikel kecil secara sederhana dapat menggunakan palu sedangkan secara modern dapat menggunakan mesin disc mill.

Brennan membedakan 4 jenis mesin penepung berdasarkan gaya yang bekerja mesin didalamnya : (1) penepung tipe palu/hammer mill, (2) penepung tipe silinder/roller mill, (3) penepung bergerigi/disc mill, (4) penepung tipe pisau/cutter mill [4]. Semua jenis mesin penepung bertujuan untuk menghancurkan bahan terutama yang berbentuk biji-bijian. Teknologi Disc mill merupakan kombinasi 
antara mesin hammer mill dan roller mill yang menggunakan penekanan dan pukulan pada bahan yang akan direduksi menjadi ukuran yang lebih kecil [5].

Mesin disc mill memiliki fungsi utama untuk mencacah dan menghancurkan bijibijian menjadi tepung. Mesin disc mill banyak digunakan dalam bidang peternakan terutama dalam hal pengolahan pakan ternak. Bahan-bahan yang umumnya diolah oleh mesin disc mill seperti beras, merica, kedelai, jagung, dan bumbu-bumbu kering [5]. Agar menghasilkan tepung yang berkualiats baik, umumnya bahan yang akan ditepung dikeringkan terlebih dahulu. Discs are widely used in the agricultural, wood, mining and chemical indus artinya disc mill banyak digunakan di industri pertanian, kayu, pertambangan dan kimia [6].

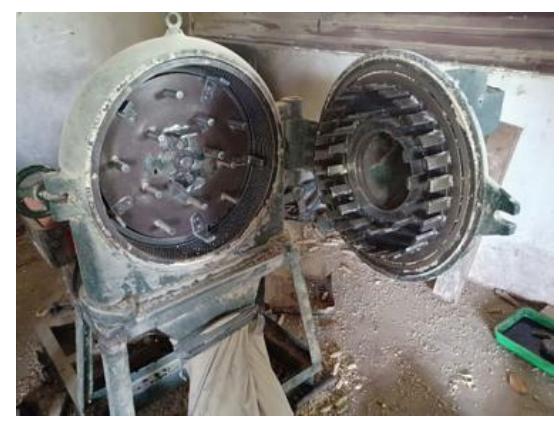

Gambar 1. Mesin disc mill Budi Asih

Prinsip kerja mesin disc mill yaitu bongkol jagung dimasukan ke dalam hopper lubang pemasukan, setelah bongkol jagung masuk maka akan langsung ditumbuk oleh pisau yang berbentuk balok yang berputar dikombinasikan dengan pisau penepung statis, satu lingkaran penuh mesin berputar dan memotong bongkol jagung. Pisau akan menepung dengan kecepatan tinggi dan menghasilkan bongkol jagung dalam kondisi halus.

Bongkol jagung yang telah halus akan terdorong oleh pisau potong dan jatuh kebawah melewati rumah tepung melalui saringan. Kemudian disalurkan ke lubang pengeluran tepung, bongkol jagung yang telah menjadi komponen kecil akan disalurkan ke pengeluaran mesin penepung. Perputaran mesin didistribusikan tenaga oleh motor listrik yanma yang kemudian mengerakan v-belt sebagai pengerak pisau pemotong mesin yang disalurkan oleh poros tengah. Cara pengisian bongkol jagung ke dalam hopper dilakukan secara manual oleh satu orang operator mesin. Ditambahkan Sofyan Assauri, perawatan mesin disc mill terdiri dari perawatan preventif dan perawatan korektif [7]. 
Setyautami menyebutkan bahwa kualitas maksimalnya hasil penepungan dapat dilihat dari halusnya bongkol jagung yang sudah dimasukan ke dalam mesin disc mill [8]. Berikut bagan prinsip kerja mesin disc mill ditunjukan oleh gambar 2.

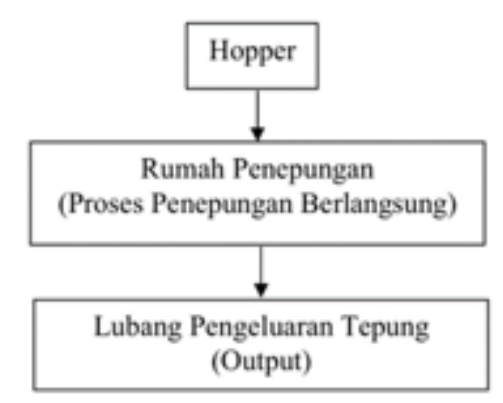

Gambar 2. Prinsip kerja mesin disc mill

Mesin disc mill digunakan oleh industri ternak skala besar ataupun kelompok ternak skala kecil. Kelompok ternak budi asih yang terletak di kabupaten Subang, Jawa barat merupakan salah satu kelompok ternak sapi yang tergabung dalam Sentra Peternakan Rakyat (SPR) yang fokus pada pembibitan sapi lokal dan pembuatan pakan ternak untuk peternak sapi di kabupaten Subang. Pakan ternak berjenis ruminansia yang terdiri dari limbah jagung, dedak, ampas kecap, mineral, urea dan garam setiap harinya dibuat oleh kelompok ternak Budi Asih dengan bantuan mesin hammer mill sebagai penghancur bongkol jagung.

Kelompok ternak Budi Asih memiliki mesin disc mill yang normalnya berkapasitas $180 \mathrm{~kg} / \mathrm{jam}$ yang didalam proses penghancuran bongkol jagung mengalami kendala sehingga proses penghancuran bongkol jagung menjadi tidak optimal. Berdasarkan hasil observasi dan wawancara peneliti dengan ketua kelompok ternak Budi Asih, didapati berbagai kendala yang dialami oleh mesin disc mill, kendala tersebut yaitu : (1) terjadi kelonggaran pisau pemotong mesin disc mill yang diakibatkan oleh hancurnya bearing poros mesin, (2) kerja mesin terlalu berat sehingga $v$-belt pendistribusi tenaga mesin mengalami kerusakan, (3) belum adanya jadwal perawatan mesin rutin sehingga memperbesar peluang penurunan kondisi mesin disc mill.

Dengan dilakukannya penelitian ini diharapkan dapat memperbaiki kerusakan yang terjadi pada mesin disc mill milik kelompok ternak budi asih dan memberikan edukasi dalam proses perawatan mesin disc mill tersebut. 


\section{METODE PENELITIAN}

Penelitian akan dilaksanakan di kelompok ternak Budi Asih kecamatan Cipunagara yang bergerak di bidang pembuatan pakan dan pembibitan sapi lokal. Tahapan penelitian ini yaitu studi literatur, perbaikan mesin, perawatan mesin, dan uji kinerja mesin disc mill.

Studi literatur dilakukan di perpustakaan Politeknik Negeri Subang dengan cara pengumpulan data yang terkait tentang permesinan dan pengolahan pakan ternak, selanjutnya dilakukan observasi di kandang kelompok ternak budi asih untuk melihat kondisi kerusakan yang dialami oleh mesin disc mill.

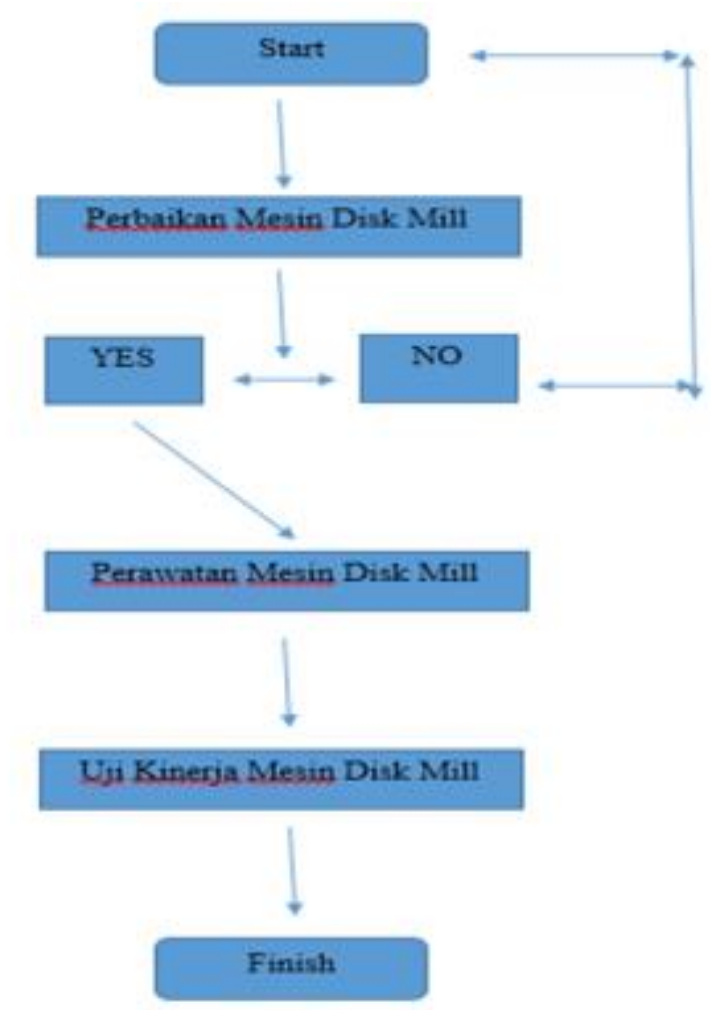

Gambar 3. Tahapan penelitian

\section{HASIL DAN PEMBAHASAN}

\section{a. Perbaikan Mesin Disc Mill}

Setelah dilakukan observasi, peneliti mendapati beberapa kerusakan yang menyebabkan kerja mesin disc mill menjadi tidak optimal, yaitu : (1) terjadi kelonggaran pisau pemotong mesin disc mill yang diakibatkan oleh hancurnya bearing poros mesin, (2) kerja mesin terlalu berat sehingga v-belt pendistribusi tenaga mesin mengalami kerusakan. Sehingga perlu dilakukan pergantian bearing pada poros dan pergantian v-belt sebagai pendistribusian tenaga. 
Sebelum melakukan perbaikan, disediakan terlebih dahulu alat dan bahan yang digunakan untuk melakukan perbaikan. Alat dan bahan tersebut, antara lain:

1.Tool box lengkap (kunci ring dan pas)

2. WD-40

3. Tang

4. Palu

5. Obeng plus dan min

6. Gerinda

7. Mata Gerinda
8. Tracker

9. Jangka Sorong

10. Mistar

11. Minyak gemuk

12. Oli

13. Kain Majun

14. Amplas Halus

\section{b. Perbaikan Pergantian Bearing Poros Engkol dan V-Belt}

Kelonggaran terjadi pada poros pengerak pisau pemotong mesin disc mill, adapun langkah-langkah pembongkaran dan pergantian bearing yang rusak adalah sebagai berikut:

1) Buka pengunci/pin bagian depan mesin disc mill

Setelah alat dan bahan disiapkan mesin, buka bagian depan mesin disc mill yang berupa pisau pemotong dan saringan, lepaskan saringan dari rumah mesin disc mill kemudian ambil palu dan pahat untuk memutar pengunci pisau pemotong, kendorkan kearah kiri secara perlahan.

2) Pisahkan pisau pemotong mesin dan saringan dari rumah mesin Disc Mill

Pisau pemotong merupakan komponen utama dalam proses penepungan bongkol jagung, saringan merupakan komponen yang menyaring material jagung dengan ukuran kecil. Apabila ukuran jagung masing belum halus, maka mesin secara otomatis memutar kembali bongkol jagung yang belum halus.

3) Lepaskan sabuk v-belt dengan cara mengendorkan mur pengunci

Setelah pisau dan saringa dilepaskan, kemudian kendorkan mur belakang pengikat rumah mesin yang simetris dengan crank shaft. Kendorkan mur pengikat kemudian angkat sabuk v-belt yang rusak.

4) Kemudian pukul poros engkol ke arah belakang menggunakan palu

Setelah v-belt dilepas, ambil palu dan bahan obeng kemudian pukul perlahan mulai dari depan kearah belakang, pastikan tidak terjadi kesalahan pukul agar tidak menimbulkan kelecetan. 
5) Setelah poros engkol dan bearing keluar, kemudian gunakan traker

Traker digunakan untuk melepaskan puli dan bearing yang terhubung di poros. Traker bekerja dengan gaya tekan kepada benda, sehingga benda bisa keluar dari porosnya. Hal yang perlu diingat adalah ukuran dan daya jangkau traker berbedabeda sehingga pemilihan traker sangat penting dalam pengaplikasiannya.

6) Lepaskan bearing pada poros engkol, kemudian diukur menggunakan jangka sorong.

Pengukuran dimaksudkan untuk mengukur diameter dalam dan diameter luar bearing dengan tujuan mencari bearing pengganti dengan ukuran yang sama. Setelah diukur diameter dalam bearing yang akan diganti adalah 45,01 dengan skala 0,002 .

7) Amati kerusakan yang terjadi pada bearing/poros engkol

Poros engkol sebagai tempat dudukan bearing sering mengalami keausan, hal ini dikarenakan beban kerja yang terlalu berat dan kurangnya pelumasan yang dapat menyebabkan keausan. Setelah diperiksa poros engkol mesin disc mill mengalami keausan dan bearing telah rusak. Gunakan amplas halus untuk mengurangi ketidakrataan pada poros.

8) Bersihkan poros engkol dan rumah poros engkol menggunakan oli

Langkah ini merupakan lankah lanjutan dari proses pemeriksaan diatas, sediakan oli untuk melumasi poros engkol sehingga poros engkol dapat berputar secara maksimal dan mengurangi resiko keausan.

9) Ganti bearing yang rusak menggunakan poros engkol se-tipe

Setelah didapati bahwa bearing telah rusak dikarenakan kerja yang terlalu berat, maka kita harus mengganti bearing yang baru dengan ukuran se-tipe agar saat memasukan bearing ke poros tidak mengalami kendala.

10) Pasang kembali bearing kepada poros engkol menggunakan traker

Setelah bearing dengan ukuran se-tipe didapat, makan langkah selanjutnya adalah memasukan bearing poros engkol. Selanjutnya pasangkan poros engkol ke badan mesin dan masukan puli menggunakan traker.

11) Berikan minyak gemuk disekitar poros engkol dan bearing

Olesi semua bagian poros dan bearing dengan minyak gemuk untuk mengurangi resiko keausan pada komponen mesin yang bekerja dan saling bergesekan. 
12) Pasang kembali poros engkol

Pemasangan poros engkol harus dilakukan secara seimbang. Artinya masukan dulu poros engkol dan bearing pertama dari depan, sedangkan bearing kedua dimasukan ke bagian belakang mesin.

13) Pasang kembali pisau pemotong dan saringan

Pasang kembali pisau pemotong ke rumah mesin bagian depan kemudian kunci dengan menggunakan pin. Setelah dilakukan penguncian, kelonggaran mesin tidak terjadi lagi sehingga kerja mesin bisa lebih optimal. Selanjutnya pasang saringan sebagai penyaring bongkol jagung yang telah hancur menjadi bagian-bagian kecil.

14) Pasang kembali v-belt baru yang se-tipe

Pemasangan v-belt yang baru se-tipe dengan cara mengkendorkan mur pengunci belakang mesin dengan kunci pas 19, kemudian masukan sabut v-belt dan simetriskan dengan puli yang terhubung dengan poros engkol.

15) Bersihkan semua komponen dengan kain majun

Ini merupakan proses finishing, yaitu untuk memastikan kondisi mesin bersih dan siap kerja.

\section{c. Maintenance Mesin Disc Mill}

Jenis dan Jadwal perawatan mesin disc mill divalidasi oleh ahli dalam bidang perawatan mesin yaitu dosen prodi perawatan dan perbaikan mesin Politeknik Negeri Subang. Perawatan dilakukan secara berkala perbulan. Berikut jadwal perawatan perbulan mesin disc mill.

Tabel 1. Jadwal Maintenance

\begin{tabular}{|c|c|c|c|c|c|c|c|c|}
\hline \multirow[t]{2}{*}{ No } & \multirow{2}{*}{$\begin{array}{c}\text { Nama } \\
\text { Komponen }\end{array}$} & \multicolumn{4}{|c|}{ Jenis Perawatan } & \multirow[t]{2}{*}{ Cara Periksa } & \multirow[t]{2}{*}{ Cara Perawatan } & \multirow{2}{*}{$\begin{array}{c}\text { Jumlah Jam } \\
\text { Perawatan }\end{array}$} \\
\hline & & I & s & MI & 0 & & & \\
\hline 1 & Saringan & $\sqrt{ }$ & & & & $\begin{array}{l}\text { Pemeriksaan secara } \\
\text { Visual }\end{array}$ & $\begin{array}{l}\text { Bersihkan saringan dan } \\
\text { cek keausan }\end{array}$ & 10 Menit \\
\hline 2 & $\begin{array}{l}\text { Pisau } \\
\text { pemotong }\end{array}$ & $\sqrt{ }$ & & & & $\begin{array}{l}\text { Pemeriksaan secara } \\
\text { Visual }\end{array}$ & $\begin{array}{l}\text { Bersihkan dan berikan } \\
\text { minyak gemuk }\end{array}$ & 10 Menit \\
\hline 3 & Air Radiator & $\sqrt{ }$ & & & & $\begin{array}{l}\text { Menggunakan Water } \\
\text { Level }\end{array}$ & $\begin{array}{l}\text { Bersihkan air dari } \\
\text { kotoran dan kerak }\end{array}$ & 10 Menit \\
\hline 4 & $\begin{array}{l}\text { Poros } \\
\text { Engkol }\end{array}$ & & $\sqrt{ }$ & & & $\begin{array}{l}\text { Menggunakan Jangka } \\
\text { Sorong }\end{array}$ & $\begin{array}{l}\text { Lumasi dengan minyak } \\
\text { gemuk dan cek keausan }\end{array}$ & 20 menit \\
\hline 5 & V-Belt & $\sqrt{ }$ & & & & $\begin{array}{l}\text { Pemeriksaan Secara } \\
\text { Visual }\end{array}$ & $\begin{array}{l}\text { Bersihkan dari kotoran } \\
\text { yang menempel }\end{array}$ & 10 menit \\
\hline 6 & Bearing & & & & $\sqrt{ }$ & $\begin{array}{l}\text { Bonglcar } \\
\text { Menggunakan Traker } \\
\text { dan cek ukuran } \\
\text { menggunakan jangka } \\
\text { sorong }\end{array}$ & $\begin{array}{l}\text { Lumasi minyak gemule } \\
\text { ganti bearing }\end{array}$ & 120 Menit \\
\hline & & & & & 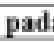 & Mesin Disk Mill & & 180 Menit \\
\hline
\end{tabular}




\section{d. Uji Kinerja Mesin}

Mesin disc mill yang telah diperbaiki bearing dan sabuk v-belt nya kembali di running mesin selama 120 menit non stop, hasil yang didapatkan adalah mesin dapat menepung bongkol jagung sebanyak $180 \mathrm{~kg} / \mathrm{jam}$.

\section{KESIMPULAN}

a. Alat dan bahan yang digunakan dalam proses repair mesin disc mill adalah tool box lengkap (kunci ring dan pas), WD-40, tang, palu, obeng plus dan min, gerinda, mata gerinda, tracker, jangka sorong, mistar, minyak gemuk, oli, kain majun, dan amplas halus;

b. Langkah-langkah perbaikan bearing dan sabuk v-belt pada mesin disc mill adalah membuka pengunci mesin disc mill bagian depan, memisahkan pisau pemotong dan saringan dari rumah mesin disc mill, melepaskan sabuk v-belt dan mur pengunci, lepaskan poros engkol dengan menggunakan palu, gunakan traker untuk melepaskan puli dan bearing, ukur diameter bearing menggunakan jangka sorong, amati kerusakan pada poros engkol dan bearing, berikan oli pelumas pada poros engkol, ganti bearing se-tipe yang baru, pasang kembali bearing ke poros engkol, berikan minyak gemuk pada bearing, pasang kembali poros engkol ke mesin disc mill, pasang kembali pisau pemotong dan saringan, kendorkan mur dan pasang kembali sabuk v-belt yang baru, langkah terakhir bersihkan mesin dengan kain majun;

c. Perencanaan perawatan mesin melalui validasi ahli, perawatan yang dipilih yaitu perawatan bulanan dengan metode ISMO.

\section{DAFTAR PUSTAKA}

[1] Wahyudin, dkk., " Respons tanaman jagung (Zea mays L.) akibat pemberian pupuk fosfat dan waktu aplikasi pupuk hayati mikroba pelarut fosfat pada Ultisols Jatinangor", Universitas Padjajaran Bandung, 2017.

[2] Septera, “ Rancang Bangun Mesin Penghancur Bongkol Jagung untuk Campuran Pakan Ternak Sapi Kapasitas Produksi 30kg/jam”, Politeknik Negeri Sriwijaya Palembang, 2015. 
[3] Zulkarnain, Slamet, dan Hidayat, Perancangan Mesin Hammer Mill Penghancur Bongkol Jagung dengan Kapasitas 100kg/jam Sebagai Pakan Ternak. Kudus, Statif, 2014.

[4] Brennan, J.G., Butters, J.R., Cowell, N.D. dan Lilly, A.E.V., Food Engineering Operations 3 th Ed., New York, Elsevier Publishing Co., 1990.

[5] Rohman, F., "Karateristik Mesin penepung Disc Tipe FFC 23”, Universitas Diponegoro Semarang, 2016.

[6] Oduntan, O. dan Omitoyin,B., "Wear of disc hammer in wet grinding processes on groundnut cake for fish feed production", University of Ibadan Nigeria, 2016.

[7] Assauri, Sofyan, Manajemen Produksi dan Operasi. Jakarta, Lembaga Penerbit Fakultas Ekonomi Universitas Indonesia, 2004.

[8] Setyautami, K., "Uji Performance Mesin Penepung Tipe Disc (Disc) untuk Penepungan Juwawut", Institut Teknologi Bogor, 2008. 